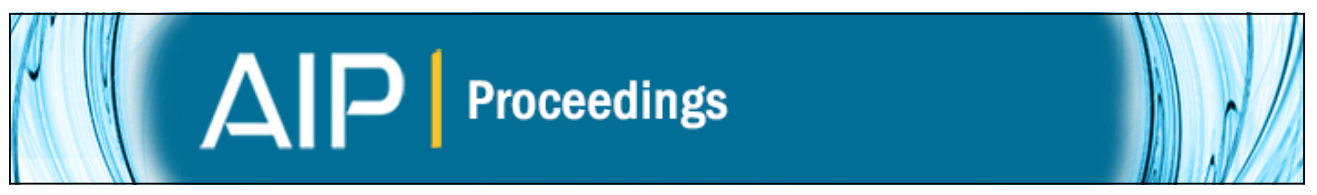

\title{
Design Of Innovation In A Technical Subject
}

D. Juárez, M. A. Peydró, M. J. Reig, and F. Parres

Citation: AIP Conference Proceedings 1181, 738 (2009); doi: 10.1063/1.3273695

View online: http://dx.doi.org/10.1063/1.3273695

View Table of Contents:

http://scitation.aip.org/content/aip/proceeding/aipcp/1181?ver=pdfcov

Published by the AIP Publishing

\section{Articles you may be interested in}

Mathematical Education In The Bulgarian Technical Universities

AIP Conf. Proc. 1410, 375 (2011); 10.1063/1.3664392

Innovative Technical Issues In The Subject Industrial Processes

AIP Conf. Proc. 1181, 722 (2009); 10.1063/1.3273693

Parameterized CAD techniques implementation for the fatigue behaviour optimization of a service chamber

AIP Conf. Proc. 1181, 638 (2009); 10.1063/1.3273685

Conditioning of Model Identification Task in Immune Inspired Optimizer SILO

AIP Conf. Proc. 1174, 172 (2009); 10.1063/1.3256245

Direct search for global minimum in neural network

AIP Conf. Proc. 519, 655 (2000); 10.1063/1.1291638 


\title{
Design Of Innovation In A Technical Subject
}

\author{
Juárez D.; Peydró M.A.; Reig M.J.; Parres, F. \\ Mechanical and Materials Engineering Department \\ Valencia Polytechnic University (Alcoy Campus) \\ Plaza Ferrándiz y Carbonell, śn 03801 Alcoy - España \\ diuarez@mcm.upv.es.
}

\begin{abstract}
The greatest motivation found in the teaching of the subject Mechanical Technology is the ability to speak to students about manufacturing technologies. The main objective of learning in this subject is a global vision of the manufacturing process, and its optimization in terms of applicability to the real world. The best way for students to learn these concepts is for the teacher to explain them with a more global view aimed at reaching a comprehensive vision with a high degree of detail.
\end{abstract}

Keywords: Educational innovation, Technical subject, Engineering, Computer application.

PACS: 80

\section{INTRODUCTION}

In Mechanical Technology, a subject taught in the second year of Industrial Engineering, the greatest motivation for the teacher is the ability to talk to students about the manufacturing technologies on which they plan to apply all knowledge and skills they acquire in other subjects.

The main objective of learning in this subject is the overview of the manufacturing process and that the student be trained in the criteria necessary to choose the most suitable technology for the type of product manufacturing, and optimize its manufacturing process.

The best way for students to learn these concepts is to explain the concepts with a more global point of view (products which can be manufactured by selecting a particular technology and machines that allow it), until reaching a detailed understanding (calculations). 


\section{EXPERIMENTAL}

\section{Responsibility for education}

The main responsibilities of teaching can be summarized as:

- Study, work and research to maintain the highest professional standards of knowledge and its transmission.

- Transmit, without omissions, knowledge leading to better training of learners.

- Collaborate actively in the organization of teaching.

- Evaluate the knowledge of students fairly and without distinction of any kind.

- Reflecting on those areas of their teaching that need improving.

- Share knowledge and experience with younger teachers of one's Department or Center.

- Document how teaching has evolved over time.

\section{Methodology of teaching}

The theory lectures will be $80 \%$ teacher oriented, with a teaching scheme based on:

- Start: daily programme, refresher + queries.

- Development: power point slides + video.

- Conclusion: review concepts + queries. A practical example.

The remaining $20 \%$ of the lectures will focus on problems based on computer applications and group dynamics.

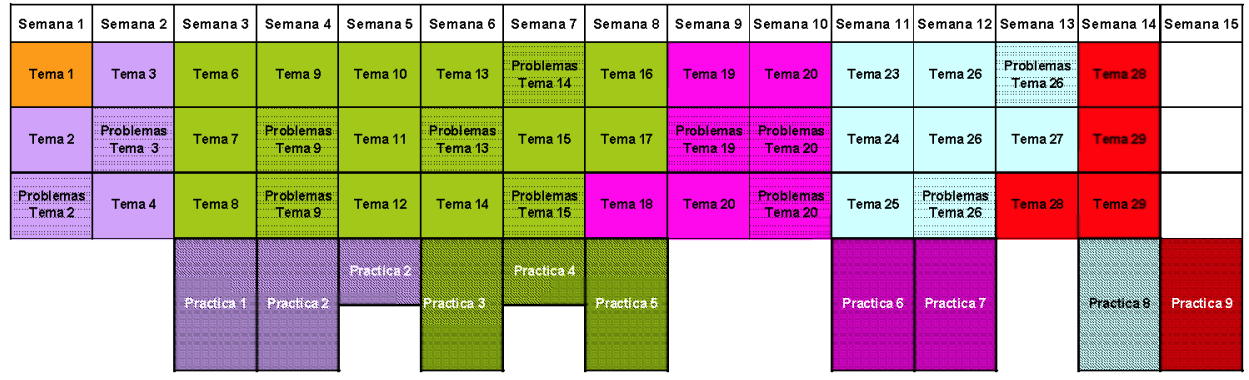

FIGURE 1. Programme of the subject.

The evaluation of this part will be based on theoretical and practical review work, with a value of $50 \%$ each part.

The practical classes will focus on the laboratory. They will be descriptive and each will cover a practical technology. The student will develop a practical work in business, which will represent everything covered in the subject. 
TABLE 1. Practice Programme.

\begin{tabular}{llc}
\hline N & \multicolumn{1}{c}{ Practice Title } & Hours \\
\hline 1 & Introduction and handling of equipment and measuring instruments. Measuring & 2 \\
& $\begin{array}{l}\text { angles and lengths. } \\
2\end{array}$ & Introduction to the measurement of shapes and position in CMM. \\
3 & Mold Shaping. & 2 \\
4 & Plastic deformation Shaping. & 4 \\
5 & Electric arc welding with coated electrode. & 4 \\
6 & Revolving parts Machining: turning and boring. & 4 \\
7 & Prismatic parts and holes machining: milling and grinding. & 4 \\
8 & Polymeric materials Shaping: injection. & 2 \\
9 & Numerical control machine tool: Mill and Lathe. & 4 \\
\hline
\end{tabular}

The assessment practices will be based on attendance, at least $80 \%$, and students must demonstrate the ability to work in a group, giving reports to the rest of the class.

Printed copies of the documentation and transparencies can be obtained from the microweb of the university.

\section{Innovation in education}

The teacher must strive to ensure that classes are entertaining, conceptually complete, with a vision and practical application that has an explicit link with the environment, schools, certification and other subjects they are studying or intending to pursue.

Refocus the topics on the agenda, making the student see "the tree while seeing the forest." Further topics, also seen as connected with other subjects and with potential jobs (the goal of certification) in which they can implement their knowledge, and with businesses in the area etc.

The ideas generated for the design of innovation are as follows:

- Creation of computer applications to resolve problems of each technology.

- Incorporating a graphical simulation that allows the student to understand the process from the inside.

- Real practical case at the end of the lesson, explained by the teacher.

- Incorporation of lectures given by experts and / or alumni currently working on technologies is something that enriches the subject and motivates the student to continue in their daily work.

The assessment of innovation is based on the following parameters:

- Marks from surveys I.C.E.

- Increased number of practical examples in class.

- Number of applications for copies of applications / direct downloads via intranets. 


\section{RESULTS}

The evidence of good performance, by students and colleagues, are:

- Positive developments in surveys.

- Bancaja Awards for end of degree projects (5)

- Reports from people who have recruited students of the subject.

- Increase in the enrollment of the subject as a result of the recommendation of students who have studied in previous years.

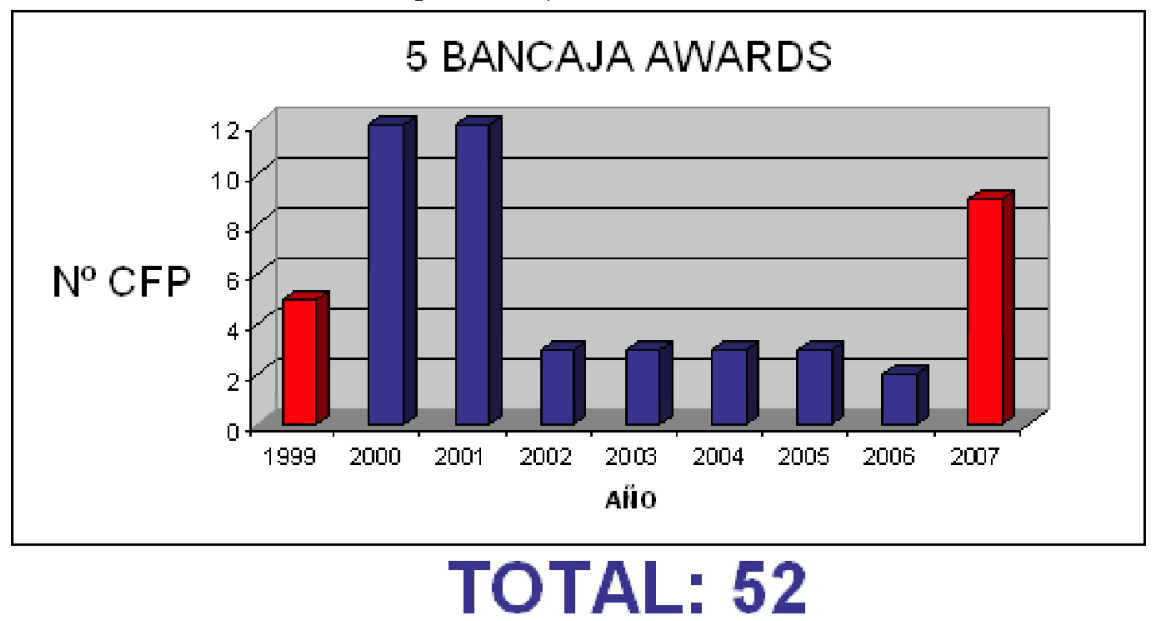

FIGURE 2. Graph showing the trend in the number of projects winning prizes.

A result of the initiative is the companies that have received students for their end of degree project, which include the following:

- Menaplast, S.L. (Ibi - Alicante - Spain)

- Feber, S.L. (Ibi - Alicante - Spain)

- FAMOSA (Onil - Alicante - Spain)

- Motores Carchano, S.L. (Alcoy - Alicante - Spain)

- $\quad$ Rasilán, S.A. (Ontinyent - Valencia - Spain)

- Saneamientos Colón, S.L. (Alcoy - Alicante - Spain)

- IMPURSA (Alcoy - Alicante - Spain)

- Vaplast, S.L. (Ibi - Alicante - Spain)

- Bolaseca, S.L. (Torres de Cotillas-Murcia - Spain)

- Clece, S.A. (Murcia - Spain)

- Montes Tallón, S.A. (Alicante - Spain)

- $\quad$ Crearplast, S.L. (Ibi - Alicante - Spain)

- Gaviota SIMBAC, S.L. (Sax - Alicante - Spain)

An average of 15 student practical projects in businesses in the area have culminated enriching experiences for the students in which they have had the opportunity to put their knowledge into practice. 
Finally, we should outline the goals or objectives both in the short term (one year) and long term (three or more years):

- In planning:

- Reassessment throughout the course and creation of new notes.

- Assign a time to each subject and stick to it..

- Using other methods apart from the teacher based lesson.

- In action:

- Explain in class what is really important.

- To conduct activities in class.

- In review:

- Assess at several points of the course.

These same goals are the goals for further progress in improving this subject. 